ISSN: 0213-2052 - eISSN: 2530-4100

DOI: https://doi.org/10.14201/shha202038217243

\title{
A FIFTH-CENTURY «GALLIC EMPIRE»: HISPANIA AS PART OF CONSTANTINE III'S USURPATION ${ }^{1}$
}

\author{
Un "Imperium Galliarum" en el siglo v: \\ Hispania y la usurpación de Constantino III
}

\author{
María FERNÁNDEZ PORTAENCASA \\ Universidad Carlos III de Madrid \\ fportaen@hum.uc3m.es
}

Fecha de recepción: 23-09-2019; aceptación definitiva: 21-2-2020

ORCID: https://orcid.org/0000-0002-7649-5834

ABSTRACT: This paper follows the route of the usurper Constantine III since he was made emperor by the troops in Britain in 407 A. D., until his defeat under the magister militum Constantius. Conceived as a whole - and not, as it usually is, in a fragmentary and marginal way -, and providing for the first time a precise chronology, this episode contributes to a better understanding of the developement of political, social and military structures in the western part of the Empire during the first years of the

1. This paper is, to a large extent, the result of my master's thesis, supervised by Prof. R. Sanz, whose patient teaching, support, corrections, and guiding through countless office hours are responsible for almost everything of value that can be read here. The remaining mistakes are my sole responsibility. More than sixty years ago, Oxford professor and occasional member of the Inklings C. E. Stevens, published 'Marcus, Gratian, Constantine' in number 35 of Athenaeum, back in 1957, of whose lecture I have greatly benefited in regard to unravelling the fascinating story of Constantine III. The last words on his paper are still relevant today and that is why, in gratitude, I am borrowing them and making them my own, for, like him, 'I should like to hope that the efforts which I have made to unravel the story are not unworthy of the story itself'. 
5th century. Constantine's usurpation was planned upon the model of the Imperium Galliarum, and its hatching meant great modifications within its territories. In Hispania, a series of landed aristocrats related to Theodosius's family standed against the usurpers, and with private troops - recruited among their own slaves and clients -, they started a war against the new regime. Despite losing it, this had severe consequences in the province's politics. After Constantine mastered the ruledom over both Gaul and Spain, as well as Britain, he was betrayed by his general Gerontius. During their confrontation, Suebi, Alans, and Vandals entered the Iberian Peninsula. In the end, Honorius was able to take control again and defeat the usurpers, but the consequences for the Hispanias's demography would prove themselves to be indelible.

Keywords: Private armies; 409 A. D.; usurpers; Britain; Honorius; Didymus and Verinianus; mass migrations; Late Roman Spain.

RESUMEN: Este artículo sigue la ruta emprendida por el usurpador Constantino III desde su proclamación imperial por parte de las tropas de Britania en el año 407 d. C. hasta su derrota bajo el magister militum Constancio. Estudiado de forma íntegra -y no, como es habitual, de manera fragmentaria y marginal-, y por primera vez estableciendo una cronología precisa, este episodio contribuye a una mejor comprensión del desarrollo de las estructuras políticas, sociales y militares en el Imperio Occidental durante los primeros años del siglo v. La usurpación de Constantino fue planificada siguiendo el modelo del Imperium Galliarum, y su eclosión supuso importantes modificaciones en los territorios que abarcaba. En Hispania, una serie de miembros de la aristocracia territorial, emparentados con la familia de Teodosio, se levantaron contra los usurpadores. Con ejércitos privados (compuestos por tropas reclutadas de entre sus propios esclavos y clientes), comenzaron una guerra contra el nuevo régimen, y, a pesar de no ganarla, sus acciones provocaron severas consecuencias en las políticas provinciales. Tras hacerse con el control de Galia e Hispania, además de Britania, Constantino fue traicionado por su general Geroncio. Durante su confrontación, suevos, vándalos y alanos irrumpieron en la Península. Finalmente, Honorio logró retomar el control y derrotó a los usurpadores, pero las consecuencias para la demografía de Hispania demostraron ser irreversibles.

Palabas clave: Ejércitos privados; 409 d. C.; usurpadores; Britania; Honorio; Dídimo y Veriniano; migraciones masivas; Hispania tardorromana. 


\section{INTRODUCTION}

In the year 415 A. D., a man named Eusebius Sophronius Hieronymus, best known as Jerome of Stridon, while writing one of his many and famous letters, referred to Britain as a land 'fertile in usurpers'2. He was not misguided, as it had been barely four years since the fall of one of the most notable usurpers that the island ever produced, whose actions had left an indelible mark on the continent.

Back in the last months of 406, the troops cantoned in Britain, fearful of the news on invasions coming from the continent, and feeling abandoned by Honorius's misrule, mutinied ${ }^{3}$. They made Marcus, possibly the Comes Britanniae 4 , emperor. Then, not being pleased with his behaviour, they murdered him and had him replaced with Gratianus, who apparently was native to Britannia: municeps eiusdem insulaes. Although he was given an imperial guard, four months after being risen he suffered the same fate as his predecessor, probably around March or April 407. All sources $^{6}$ agree that his deposition had the immediate consequence of the elevation of Constantine to the throne, whose success, or at least his ability to hold his position more than a few months, earned him the epithet of 'the third'.

2. Hier., Epist., 133. Britannia, fertilis prouincia tyrannorum.

3. Zos. 6. 2, 1; 6. 3, 1; Soz. 9. 11, etc.

4. Frere 1973, 364. Apparently, there were three military commands in Britain at the time. The Comes Britanniae (N.D. Occ., XXIX), the Dux Brittaniarum (N.D. Occ., XL) and the Comes litoris Saxonici per Britanniam (N.D. Occ., XXVIII). The latter were in command of limitanei, whilst the first one was in charge of comitatenses, stationed in Britain in an unknown date. Other defences (such as the Cardiff Fort or the Werry Wall at Lancaster) do not figure in the Notitia (Esmonde-Cleary 1989, 53), which of course is not entirely reliable.

5. Oros. 7. 40, 4. This municeps has been traditionally understood (Cf. STEvens 1957, 322; FreRe 1973, 364, et al.) as curialis, not as a person with local origo. For some ( $C f$. SANZ Huesma 2005, 322), this would mean that Gratian was nothing but a mere puppet operated by Constantine. Even if Gratian was an actual municipal senator, which is doubtful, that assertion cannot be deduced by what is known from the sources. There are some contemporary examples of municeps meaning curialis (C. Th. 12. 1, 89, or CAssIOD. Var. 7. 47, 3 ), but there is no proof that the original meaning had been lost, and it would be more plausible to think of a mistake of Orosius than having a member of the urban aristocracy being made Emperor by troops who wanted to become emancipated from the Empire and avoid the external perils.

6. Oros. 7. 40, 4; Soz. 9. 11; Zos. 6. 2, 2, Olym. Frag., 13.

7. Not because he was the third in this series of usurpations, of course, but because his usurpation was successful enough to grant him the official recognition as emperor, the third one who beared this acclaimed name. 
The dating of the original mutiny - the one that placed Marcus on the throne - is not a minor thing, as it determines the rest of the chronological sequence. Zosimus gives two contradictory testimonies; in 6. 2, 1 he places it on 407, during the seventh consulship of Honorius and the second of Thedosius, whereas in 6. 3, 1 he places it one year before, on 406. Orosius's acount ${ }^{8}$ is useless here, as he places both invasions and usurpations on the very late date of 408. Olympiodorus of Thebes is brief but clearer: he states that Marcus's rising took place before Honorius's seventh consulship9. This dating is preferable, not only because Olympiodorus is Zosimus's main source, but also for its greatest precision: the reference to 'before' the consulship probably means that it took place during the last months of 406 A. D. But Zosimus mentions the continental invasions as a major cause for the usurpations in Britain, and the date traditionally established for the crossing of the Rhine by Suebi, Vandals and Alans, though rhetoric, is the 31st December 406. If the crossing of the Rhine was on the last moments of 406, it could not be a cause for what was happening at the same time or earlier in Britain ${ }^{10}$. However, if we look closely, Zosimus ${ }^{11}$ states that the barbarians went through 'those settings', and by that he means the Alps, mentioned in the previous chapter ${ }^{12}$. Therefore, it must have been those Alpine invasions - different from the Rhine coalition, and previous to it - what created disturbances in Gaul, alerted the troops in Britain, and provoked their sedition. Many tend to emphasise the role of Suebi, Alans and Vandals, but Jerome ${ }^{13}$ points out Saxons and Herules as responisble for the chaos in Gaul. Alamanni and Burgundians must have also played an important role ${ }^{14}$, and soldiers may have chosen Marcus to honour Carausius, who defended Britain from Saxon pirates in the 3rd century, so a new pirate attack could also have had something to $\mathrm{do}^{15}$. Besides, we must not underestimate the role played by the widespread discontent among troops, especially between those cantoned in the limites, unpaid due to the lack of public funds, on account of the depletion of

8. Oros. 7. 40, 4.

9. Olym. Frag., 13.

10. M. Kulikowski $(2000,328-330)$ tried to overcome the obstacle by moving the invasions backwards one year (31st December 405). This is little convincing, and not even the easiest solution, as it would be simpler to move the dates of the British usurpations backwards (making them, for example, a consequence of Radagaisus's Italian invasion) than the Rhine crossing, which affects many other events.

11. Zos. 6. 3, 1 .

12. Zos. 6. 2, 6 .

13. HiER. Epist., 123.

14. ÁlvareZ JimÉNeZ 2013, 92.

15. STEVENS 1957, 321. 
HISPANIA AS PART OF CONSTANTINE III'S USURPATION

the territories' economy, as shown by the severe fiscal pressure imposed by the emperors of the 4th and 5th centuries. Maintaining a healthy economy seemed an impossible challenge, due to the recurrent and persistent civil wars. The situation was worsened by the currency devaluation that had taken place since the 3rd century, as the amount of silver in coins had decreased considerably, at the same pace as price inflation increased ${ }^{16}$. Troops that were denied their corresponding stipendium were prone to elevate figures such as Constantine III.

Taking all of this into account, the beginning of Constantine's reign can be established around the spring of 407. Not much is known of his life previous to his proclamation; it can be assumed that he was a Christian, as shown by the monastic condition of his eldest son, and by the behaviour displayed on his last days, and all sources describe him as a private ${ }^{17}$, supposedly only chosen for the hope emanated from his name. Constantine proved he was determined not to make them lose more time, and, at once, appointed the new generals, Justinian and Neobigast ${ }^{18}$, sending them ahead of him to Gaul, so that they could start preparing his arrival and bringing to their side the troops stationed there ${ }^{19}$.

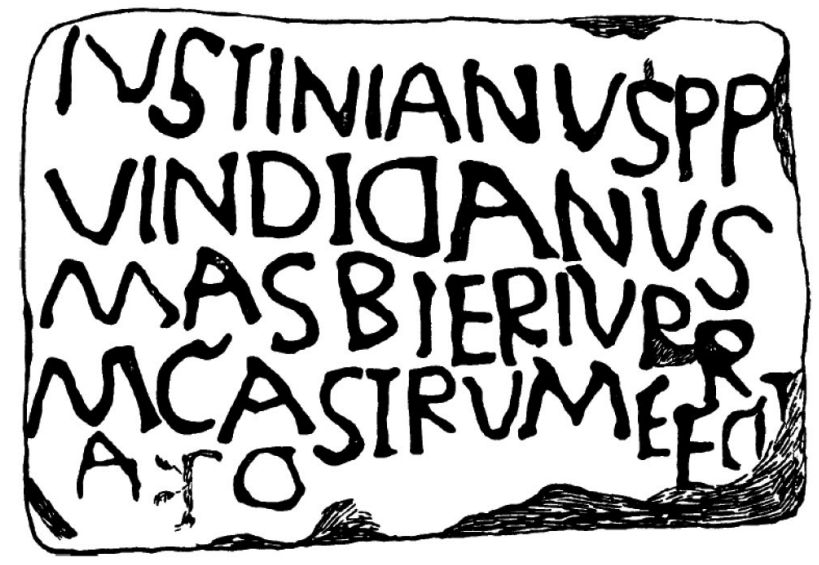

Figure 1. RIB 721. Drawn by R.G.C., 1929.

16. Cf. Depeyrot 1987 and 1996; Fernández Ubiña 1982; Callu 1969.

17. Oros. 7. 40, 4.

18. Olym. Frag., 13. An inscription from Ravenscar $(R I B 721=C I L$ VII 268) attests a soldier named Justinian responsible for the construction of several defences, identified in various works (i.e. Evans 1887, 207-209; PLRE II, Iustinianus 1) with Constantine III's general (Fig. 1).

19. Zos. 6. 2, 2. 
We must bear in mind that, from the very moment he was risen to power, it was quite clear to Constantine that his task should not be confined to a mere settlement of the situation at the north of Gaul for the sake of Britain. Rather, the fates of the whole western provinces were bound to be under his power. That was what made the difference with Marcus and Gratianus: Constantine had an actual Imperial plan. It was the scheme behind his political agenda, and therefore, what guided his actions at all times. It seems quite obvious that the activity he carried throughout the Praetorian Prefecture of Gaul included clear resemblances with Postumus and his Gallic Empire, with Magnus Maximus, and with the most successful usurper of all times: Constantine the Great ${ }^{20}$. As Stevens ${ }^{21}$ rightly spotted, the appointment of two generals of the troops in Gaul before leaving Britain "means that he was appointing two magistri militum, as they had existed when the regions of the Gallic prefecture, Gaul, Spain and Britain, had their own Augustus', that is, the Imperium Galliarum he would try to rebuild. The path he would then follow ${ }^{22}$ is the incarnation of his long-range project, built and modelled following the experience of other usurpers in the West. Perhaps his idea matured due to having others finding 'hope in his name', which sounds rather messianic, but it is even more likely that it was the opposite: when Constantine saw how he was drawn attention, he would not doubt of taking advantage of such an acclaimed anthroponym.

20. Fanning1992, 288.

21. Stevens $1957,323$.

22. It is easier to follow the story with the map (Fig. 2). Marta Guijarro has greatly contributed in its editing. It is here now thanks to her invaluable help. 
A FIFTH-CENTURY "GALLIC EMPIRE»:

HISPANIA AS PART OF CONSTANTINE III'S USURPATION

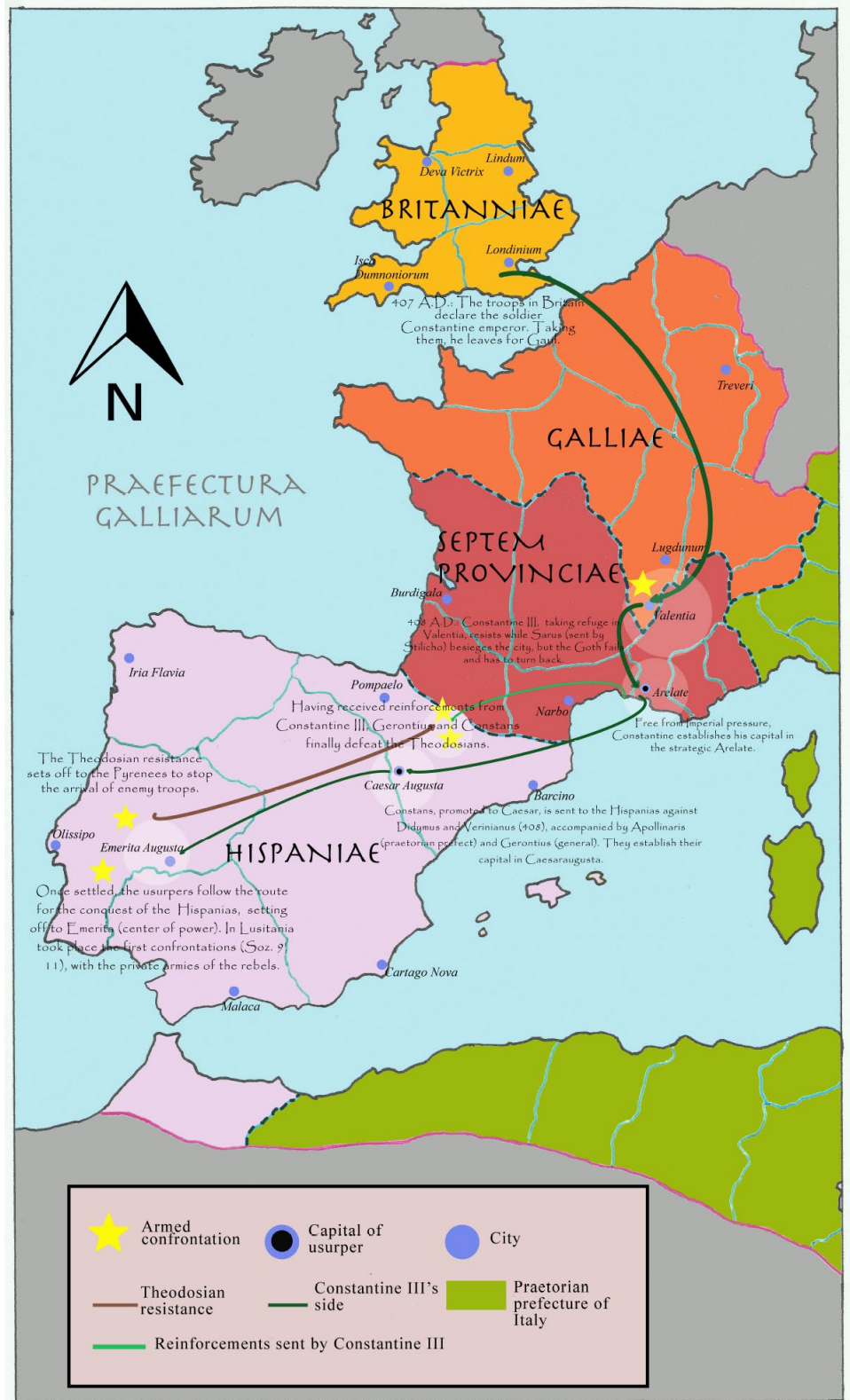

Figure 2. Map showing Constantine III's progress, from his elevation in Britain until he completely dominated the Prefecture of Gaul. Source: María Fernández Portaencasa. 


\section{En ROUTE TO THE DioEcEsis Hispaniarum}

No sooner had he arrived at Gaul and settled his capital in Arelate $^{23}$ than, while he took care of the affairs related to the barbarians and gained control over the territory, several iudices were sent under his command to the Hispanias ${ }^{24}$. Although a confluence of riots, civil disorders and tensions with those local authorities that remained loyal to Honorius would have been reasonably expectable, as a result of the imposition of this new regime $^{25}$, it did not occur. In fact, these new governors were accepted 'obediently and without difficulty', according to Orosius. Perhaps, those still faithful to Honorius did not exist at all, or maybe they could have fled, just as some of the Gallic magistrates presumably did.

Hispania, just as the rest of the provinces of the Empire, had its particular circumstances. While the Spanish provinces had been quite as neglected as the rest of the West by Honorius's misrule, and although there also existed the same menace and fear that peoples roaming through Gaul could get into their territory, the Hispano-Romans had not responded to these issues with usurpations ${ }^{26}$. It is possible that the 'obedience' with which Orosius describes the way these indices were received into the Hispanias was in fact due to that critical state: the arrival of new governors would mean an opportunity that, despite hazardous, could not be missed by a population who had seen how the imperial government had long stopped taking care of its duties and obligations with them; the feeling of having nothing to lose would be quite widespread. What was left of the exiguous militia - it could not be considered a professional army anymore - served as support for the governmental structures, which remained in place almost through force of habit, vulnerable to anyone willing to take their place. Therefore, it seems reasonable to think that this 'obedience' was really the only chance for those who did not look forward to new governors but could not afford a defence, and joining the cause would be the choice of those others who still held out hope for things improving in the Hispanias.

23. Early in 408, after having defeated Sarus - the Goth chieftain sent by Stilicho -, who beseiged him in Valentia (Zos. 5. 31, 4). Arles was a very practical city: the headquarters of the praetorian prefect had been transferred there from Trier around spring 407 (Chastagnol 1973, 33). But it also held a great symbolism: known as the Constantina urbs (Heijmans 2007, 209), it was the birthplace of Constantine II.

24. Oros. 7. 40, 5. Misit in Hispanias iudices: quos cum prouinciae oboedienter accepissent.

25. Sanz Serrano 2009, 157.

26. ARCE 2007, 36. 
However, there was an actual exception, which would bring much trouble into the plans of the usurper. Shortly after the successful pronunciamiento of Constantine's envoys in the Hispanias, a resistance movement began to take form. Despite the precarious situation in which the pair of Emperors found themselves, both in East and West ruled the Theodosian dynasty, which had managed to retain a particular popularity in the Hispanias, birthplace of Theodosius I and Arcadius, where they still had relatives. Being Gallaecian and contemporary with the events, Paulus Orosius's testimony, despite its limitations, is the one with more useful information. Two brothers, Didymus and Verinianus, decided to face up the 'tyrant', defending themselves and their homeland ${ }^{27}$.

These young men are described as 'noble and wealthy'; nevertheless, Orosius does not mention them having any actual position or appointment. Sozomen ${ }^{28}$ specifies that Didymus and Verinianus were 'relatives of Honorius' and that, previously, they had been at odds with each other, but had set their differences aside, as they found themselves 'threatened by the same danger'. He also mentions another pair of brothers or cousins, who joined their fight as well - to a lesser extent, as they lived in a different province: Theodosiolus and Lagodius ${ }^{29}$. It is quite remarkable that, being Orosius the closest to the events, he is the only author that omits the kinship shared between the Emperor and these men. Probably he was not very pleased with Honorius's disastrous way of ruling, and perhaps thought more appropriate not to associate such an emperor with the ones that he considered actual heroes ${ }^{30}$. Besides, due to the great admiration he seemed to have for them, he would try to picture their actions as more disinterested and honourable ('to defend their homeland') than ones done for mere defence of a relative, who, incidentally, was also the Emperor.

What does become clear from the texts is that, in Hispania, a series of members of families related to Theodosius's own family - who plausibly were wealthy landowners - had self-identified as the defenders of Honorius's interests ${ }^{31}$. Neither were they part of the State system (rather, they operated in parallel), nor did they belong to a landed aristocracy as such, because, even tough their financial capacity was due to their landholding, their power resided in a series of relationship and influence networks within the courtly circles (without holding actual positions), as

27. Oros. 7. 40, 5.

28. Soz. 9.11.

29. Soz. 9.12

30. Sanz Serrano 2009, 160-161.

31. Sanz Serrano 1986, 235. 
a result of their imperial kinship; something that granted them a great independence. This has made some authors think of them as actual usurpers, but far from that, Didymus, Verinianus, Theodosiolus and Lagodius, and perhaps some others whose names have been lost, would not desire more independence than the one they already enjoyed, but also would not want Constantine to deprive them of it. Defending the 'imperial rights', under the banner of their kinship, was the perfect excuse for maintaining their own status without taking on new responsibilities ${ }^{32}$.

Orosius, after emphasising their integrity, explains how they managed to coordinate the defence, which would eventually take them to the Pyrenees. In the passage ${ }^{33}$, it is said that the combatants were servants from their own estates and lands, financed and equipped by them. Sozomen $^{34}$ claims that they combined their forces, consisting mainly of armed peasants and slaves. This is a perfect example of what has been called a 'private army', something quite common at the time, which is not surprising, as it could be afforded and supported by their great riches ${ }^{35}$. According to Orosius, they gathered troops for a long time; however, and taking into account Sozomen's indication on the problems with each other that these men had had, some time ago, and how on this particular occasion they 'combined their forces', it seems more plausible that these armies were something already existing, not an ex novo creation. Given their composition, though - slaves, servants, clients, tenant farmers and, generally, workers from their own households and fields, in addition to mercenaries, and others coming from punctual levies in the surroundings -, they would not be operational at all times. Once ready, the Spanish ringleaders would go directly against Constantine's iudices. The new administration would surely be the main target of their private troops, as their major goal was to stop the instutionalisation and consolidation of this regime. News, of course, would not take long to arrive at Arles.

Constantine had two sons: Constans and Julian ${ }^{36}$, although we do not know if their names are due to an extraordinary coincidence or as a result

32. Or as put by S. MarTín $(2007,179-190)$ in a much simpler way, «es un auténtico «sálvese quien puedam; it is just the response that the wealthy landowners could give, counting on their own resources, to an unexpected crisis.

33. OROS. 7. 40, 6.

34. Soz. 9.11.

35. The phenomenon of private armies in Late Antiquity has been widely and foremost studied by R. SANz (1986, 225-264, with special attention to a brilliant definition on p. 226).

36. Olym. Frag., 13. 
of a premeditated manoeuvre of dynastic politics ${ }^{37}$. What we do know for sure, and all sources agree, is that Constantine had planned to associate his sons to his political program, and it would be the Spanish incident what would get this new stage underway. The eldest son, Constans, turned from monk into Caesar, would be responsible for stopping the Theodosian resistance in Hispania from depriving them of completing their Empire, as told by Orosius ${ }^{38}$, Sozomen ${ }^{39}$ and Zosimus ${ }^{40}$.

Orosius is the only one to mention Constans's secularization regarding these events, but it is likely that it had already taken place before leaving Britannia, and that both sons would have already been helping his father during all of the usurpation process. Olympiodorus ${ }^{41}$ also alludes to Julian's later designation as nobilissimus. Bearing in mind that until early 408 Constantine would not have yet settled in Arles, and that Didymus, Verinianus, and the rest of Spanish ringleaders, probably needed some time to hatch the plan and prepare themselves (we must not forget that, first of all, they had to put aside their differences), it would be prudent considering March or April 408 as a date for the first attacks and the subsequent reaction in Arles.

The answer that followed, besides his promotion to Caesar, meant for Constans being sent to the Hispanias, accompanied by his father's strongmen, as Zosimus tells in detail ${ }^{42}$. It is not surprising that the newly appointed Caesar came escorted by a renowned general, Gerontius, and a praetorian prefect, Apollinaris, given that, from the few data available (young, secularized not long ago, and presumably inexperienced), Constans was not exactly the ideal man for the mission that had been entrusted to him. Nevertheless, his symbolic power would indeed be quite effective among his supporters; what is more, and despite this has been ignored by most of the literature, the way in which Constans faced the situation, and the great loyalty shown to his father, demonstrate a great tenacity, which easily could have made up for his lack of experience. On his way to the Hispanias, Constantine put under his command an army made up mainly of barbarian troops, called Honoriaci, for they had

37. Both Constans and Julian (son and nephew of Constantine I) were also linked to the governing of the West, and it is unlikely that Constantine III would have missed that precise detail.

38. Oros. 7. 40, 7.

39. Soz. 9. 11.

40. Zos. 6. 4, 1.

41. Olym. Frag. 13.

42. Zos. 6. 4, 2. 
previously served as allies to the Roman army ${ }^{43}$. Next, Orosius annotates that, as a result of all these events, binc apud Hispanias prima mali labes: the wreck of the Hispanias took place.

Constantine was afraid of the hispanic Theodosians crossing the Pyrenees if he failed extinguishing the revolt, as pointed out by Zosimus ${ }^{44}$. If that were to happen, they would cover the western flank, leaving the eastern one defenceless before Honorius's legions, which could easily leap on them from Italy, meaning a definitive ending to his Empire. For that reason, Constans's mission was, both symbolic and physically, crucial for their own survival. At this point, sources, per se scarce, are particularly chaotic, fragmentary and obscure. All of them, though, contribute with some information that, taken as a whole and properly interpreted, can help to reconstruct the facts.

Orosius $^{45}$ is the briefest, as he solely informs that both brothers tried to block the Pyrenees's entrance with their private armies: qui tutari priuato praesidio Pyrenaei Alpes moliebantur. Sozomen ${ }^{46}$ claims that the Spanish attacked Lusitania together, slaying many of the soldiers sent by the usurper for their capture, and he adds that Constans's troops received some reinforcements soon after ${ }^{47}$. A little wider is Zosimus's account ${ }^{48}$, but it is also the most surprising one, as he argues that the Spanish had started the war against Constans making use of the legions of Lusitania, before being forced to use their own private troops of peasants and servants, with whom they were almost able to put him in a very difficult position, if not directly defeating him. In the view of these pieces of information, it is essential to determine a chronological order and to clarify two elements in which, one way or another, all sources insist: the leading agents (that is, the troops) and the places in which events took place.

Renatus Profuturus Frigeridus, whose work has been lost except for the fragments occasionally quoted by Gregory of Tours, is the only author to give a vital piece of information: that Constans had established in Caesaraugusta his court ${ }^{49}$. Therefore, it is plausible that, around May or June 408, Constans, Apollinaris, Gerontius, and their army, arrived in the Peninsula, settling themselves at the city nearby the River Ebro, since, not only was it still one of the main metropolises of the Hispanias (thus,

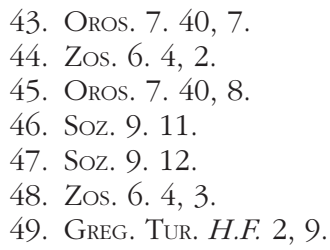


a well-communicated one), but also, barely $700 \mathrm{~km}$ away from Arles, seemed an excellent base of operations ${ }^{50}$. Once settled, they would hurry to get their troops arranged, so that the confrontation with the rebels could start as soon as possible.

The route probably took them through Emerita Augusta - consolidating their territorial control as they went -, since, not only it was the capital of the Diocese of Hispania, but also its surroundings were the area of major influence of Didymus and Verinanius at the time, and perhaps also their residence. Here is where the reference that the sources make to a confrontation in Lusitania fits; at last, the battle between Constans and his troops, and the Theodosians, took place. Zosimus's statement ${ }^{51}$ on the supposed legions of Lusitania fighting on the Spanish side also comes about at this point; however, the accuracy of this sentence seems little plausible. According to the Notitia Dignitatum, there was no such thing as an army in Lusitania in those days, and even if the Notitia is not entirely reliable, Zosimus's statement still is a piece of information which clashes with the rest of the sources' stories, not to mention that, precisely, he is one of the authors who most frequently mixes up events throughout his narration ${ }^{52}$. On the contrary, it seems that, at that time, only a few important detachments remained at Hispania - in areas such as Palencia o Santander; not a single in Lusitania -, and, with the exception of Leon, they were not made up of legions, but of auxiliary cohorts of some five hundred men. Neither it is necessary to completely refute Zosimus; it is enough to give up on the idea of a powerful, professional and huge army. A law from the late 4th century ${ }^{53}$ mentions the Burgarii, probably watchmen that served as citizen troops, very vaguely regular, but nevertheless maintained by the provincials and supervised by the governors ${ }^{54}$; this idea fits perfectly well with the situation that could be taking place at Lusitania, without forgetting that the main weight of the war would be carried out by the private forces already described.

50. There is relatively recent archaeological evidence of the importance of the Ebro valley for Constantine: the Late-Roman building of Centcelles (Tarraco), traditionally dated to the 4th century, has been identified as the central area of a military camp set up by Honorius's troops, with the objective of recovering control over the Dioecesis after the fall of the usurpers (REMOlLÀ and PÉREZ 2013, 161-186).

51. Zos. 6. 4, 3.

52. Sanz Serrano 1986, 236.

53. C.Th. 7. 14, 1.

54. Sanz Serrano 2009, 168. 
Apparently, this first assault caught Constans and Gerontius by surprise $^{55}$, and after the victory of the Theodosians, with their forces seriously decreased, they ought to ask Constantine III for reinforcements ${ }^{56}$. Only by arranging the events this way can Orosius's statement ${ }^{57}$ that Didymus and Verinianus went with their troops to defend the Pyrenees be understood ${ }^{58}$ : surely, they were trying to stop Constantine's reinforcements sent from Arles from entering the Hispanias. This time, however, they lacked fortune. The reinforcements sent by the usurper overtook them, and in this last and definitive confrontation, victory was for Constans, who devastated the private armies of the Spanish. With the war ended, Theodosiolus and Lagodius fled from Hispania, taking advantage of their imperial kinship: the first one ran to take refuge at Ravenna, with his cousin Honorius, while the second seeked the protection of Theodosius II at Constantinople ${ }^{59}$. Didymus and Verinianus suffered a worse fate: together with their spouses, they were made prisoners and lead by Constans to Arles, to appear before his father, and were shortly after executed ${ }^{60}$.

Prior to leaving, Constans made sure to have all affairs in Hispania tied up so that their rule over the Spanish provinces was effectively consolidated. Thus, he appointed his own administration, leaving in his name both civil and military magistrates ${ }^{61}$. This gives a clue of the well-being of their Empire at the moment, and also confirms the assumption that those sent from Gaul initially had been the targets of the first attacks, therefore being substituted.

Constans could have just departed directly to Arles, as he did shortly after, leaving at Caesaraugusta his court and wife - indicative that, sooner or later, he intended to return -, and Gerontius as his lieutenant ${ }^{62}$. However, before, he decided to take a measure that ended up being a huge mistake: he entrusted the Honoriaci with the vigilance of the Pyrenees' passes ${ }^{63}$, which had been traditionally guarded by local rustic troops ${ }^{64}$. It seems that the pleas and requests from the Spanish did not manage to change

55. Zos. 6. 4, 3 .

56. Soz. 9. 12.

57. Oros. 7. $40,8$.

58. ARCE 1982, 154-155.

59. Soz. 9. 12; Zos. 6. 4, 4.

60. Oros. 40. 3, 8; Soz. 9. 12; Zos. 6. 4, 3-4; 5, 1.

61. Zos. 6. 4, 3; Soz, 9. 12.

62. Greg. Tur. H.F. 2, 9.

63. Soz. 9. 12; Zos. 6. 5, 1.

64. These would be equivalent to the eastern Diogmitae or the western Saltuarii; semi-armed troops, mainly watchmen, not regular, preferable to the Limitanei for these kind of territories (ARCE 2007, 49). 
his mind, despite the fact that these traditional defences, made up of men who knew properly the paths, were the only ones to work for a correct vigilance. The insistence with which the sources refer the way these locals asked for maintaining the privilege, and the very fact that Constans preferred the ones he thought trustworthy for the task, seems to show that the peoples that were wandering through the Gallic lands were not as controlled as Constantine III thought or willed, and that they were seen by all of them as a threat. This, together with another big mistake - allowing the troops to raid over the fields of Palencia after their victory ${ }^{65}-$ would pave the way for the regime's failure. Nevertheless, for the moment, Constans went to Arles quite pleased with himself, taking to his father the news on their victory.

\section{Rise AND FALL OF THE LAST IMPERIUM GALLIARUM}

Not earlier than autumn 408 A. D. would have Constans reached Arles to meet Constantine III. Along with him came his prisoners, Didymus, Verinianus, and their wives; all of them had their throats cut shortly after ${ }^{66}$. Barely nothing is known of the following months, but the odds are that Constans stayed with his father during the winter, as the weather would not have been very appropriate to travel through the mountains, not to say that they should have loads of work ahead by then, in order to definitely consolidate their Empire. After all, the usurper had finally managed to express his political agenda on the actual map, complete, now, with the annexation of the Hispanias. That meant he could once and for all attempt his final dream: claiming his rights before Honorius.

According to Zosimus ${ }^{67}$, early on 409 an embassy of eunuchs sent from Arles arrived at Ravenna. Constantine, careful not to appear impertinent, since nothing should stand in the way of his long-awaited purple and him (not even his own pride), sent to Honorius the request to be forgiven for having agreed to take the crown, for he did not take it by his own will, but was forced to do it by the soldiers' insistence. Taking into account that, by then, fickle Honorius was isolated (presumably, under the influence of suspicious figures such as Olympius), since Stilicho had

65. Oros. 7. 40,8 .

66. Zos. $5.43,2 ; 6.5,1$.

67. Zos. 5. 43, 1-2. 
been dead five months already ${ }^{68}$, and adding his congenital weakness to the critical situation at the time (with Alaric's Goths at the gates), it is quite understandable how he eventually decided to consent obediently with his requests. For once, Honorius was positively realistic: he just could not afford one more war. If it was not political realism, then it was simple fear: Honorius saw in Constantine 'a direct threat of impending dynasty change, if ever there was one ${ }^{69}$. Zosimus points out too, as an important reason for giving in to the usurper's requests: the concern about his captive relatives, possibly already deceased by then. Hence, the embassy left Italy and returned to Arles soon after, having accomplished its task, and Constantine was able to open the New Year with the imperial robes that he received. There is a funerary inscription dating to 409, IG XIV $2559^{70}$, which reflects the joint consulship of both western Emperors: 'Here lays Eusebia (...) who shortly lived to the age of fifteen, during the eighth consulship of Honorius and the first of Constantine. The day twelve of the month of Panemos, Sunday, in peace ${ }^{171}$.

After accomplishing his aim, Constantine was able to enjoy a period of relief and serenity, although extremely short. While Constans returned to Spain, where he would supervise their control over the territory, he remained in Arles, probably very pleased with the achievements, but with his intentions set on his next ambition. If, within hardly two years, he had been able to evolve from an anonymous soldier to the master of the western triad, recognised with the purple by the Emperor himself, nothing could stop him from increasing his expansion. The distribution between Honorius and him that had seemed idyllic at first, now had fallen undoubtedly short; nevertheless, he - cunning as he was - awaited patiently for the turning up of the perfect opportunity.

It was already late 409 when, as had become usual lately, Honorius had once again troubles in his negotiations with Alaric. The Goth, who had both a statesmanship and a long-term vision much greater than the

68. He was executed late in August 408 (Zos. 5. 34, 7), due to courtly conjures. His loss was a disgrace for Honorius's regime. As J. MatTHews $(1975,283)$ rightly said, «it remained to be seen whether any of his successors [...] would be able to present policies so hopeful of success, and so realistic, as those of Stilichom. Vid. Sanz Serrano 2016, 291-309.

69. Heather 2006, 225. In fact, not only Constans had been promoted to Caesar, but also his brother Julian had probably been promoted to nobilissimus by then already (PLRE II, Iulianus 7), so it seemed clear that Constantine had his succession guaranteed.

70. The inscription was found at Trier, and the month of Panemos, from the Macedonian calendar, which is mentioned on the inscription, corresponds with June. That means that, at the latest, by summer 409, Constantine's imperial legitimation would be well widespread.

71. Translation by courtesy of Vangelis Aragiannis and Giorgos Dachris for this paper. 
Emperor's, no longer demanded gold and had reduced considerably his requests of corn and lands: of course, "he had the military power to take pretty much whatever he wanted, but was willing to trade it in for a stable peace agreement with the Roman state ${ }^{72}$. But Honorius was trapped between the rock of his indecision and the hard place of his bewilderment, and, once again, rejected Alaric's terms. As a result, Alaric returned and besieged Rome ${ }^{73}$, and Constantine III, more than probably, saw then his chance to increase his power. It is unlikely that he could feel very confident towards Honorius yet (despite the Emperor had given clear evidence that he feared him, it is true that his recognition had been utterly reluctant, and he knew Honorius would hold on any opportunity to go against him), so getting in touch with the court of Ravenna to try and create friendly relationships, did not seem superfluous. As Zosimus tells ${ }^{74}$, Constantine sent Honorius a second embassy, this time lead by Jovius ${ }^{75}$, whose mission was to ratify the already negotiated peace, and, as well, to apologise for the execution of Didymus and Verinianus (which, alegedly, had taken place without Constantine's consent or will). Probably, these matters, employed as excuses for the delivery and receipt of the embassy, were not the main concern of the usurper at all, but rather, his actual goal would be more a sounding out of the situation carried out by his envoys, looking forward to his coming Italian incursion. Zosimus continues his narration explaining how, seeing that Honorius was 'immersed in confusion', wily Jovinus used this to sweet-talk to him: he reminded the Emperor that he was not exactly in the best of positions at the moment, and suggested that it would not be very sensible to reject Constantine's peace. He also managed to promise that, in exchange to having his trust, the usurper would be happy to provide him with all the troops (from Gaul, Hispania and Britannia) needed to free Italy from her unpleasant situation.

But Zosimus, unfortunately, leaves us in suspense. Honorius's answer is a mystery, but it can be reckoned that it was far from good, perhaps due to the execution of his relatives, or to his usual scepticism. Constantine, however, was determined to seize Italy whatever the cost, so he surely had an alternative plan. If he had not managed to persuade Honorius into

72. Heather 2006, 226.

73. Before demanding Priscus Attalus to be made emperor as well, which means that by then the West had already three Augusti.

74. Zos. 5. 1, 1-2.

75. Who must not be mistaken by the praetorian prefect Jovius. This Jovius at Constantine III's embassy was relative to Paulinus of Nola (PLRE II, Iovius 1), and is portrayed by Zosimus as an educated and virtuous man. 
getting his troops into Italy under the pretext of offering help, he would have to do it without his consent. Because of that, it was probably during this trip that Constantine's emissaries contacted the magister equitum Allobich and plotted an alliance with him.

As a result of these negotiations, in which both sides would have layed the plan down, Allobich provided them with the way to introduce their troops into Italy. The personal interests that the magister equitum could have in wanting to help Constantine are unknown, although perhaps he, too, considered necessary a dynasty change. Be it as it may, things finally did not turn out as they had expected. Constantine had now promoted Constans to Augustus ${ }^{76}$, surely so that he could rule over Hispania and Gaul during his absence, and, besides, to make sure that their Empire was secure even if his plans failed and he was unable to return. Leaving his son in charge, he, as Sozomen rightly says ${ }^{77}$, crossed the Cottian Alps and went into Italy entering from Libarna. As told by the Gazan historian, when they were just about to cross the river Po, Constantine received the news of his accomplice's death. In effect, shortly before his arrival, Honorius had been informed that Allobich was under suspicion of treason, and of his presumed plans of turning Constantine into lord and master of the West, and had ordered his execution ${ }^{78}$. Immedietaly, Constantine found himself forced to abandon his plans and take refuge in Arles. The reasons of his flight are not specified, but it can be imagined that he would not be able to escape from Honorius's troops, if he finally entered, without the help that Allobich would have provided, so he did not dare to take the risk and withdrew, just on time.

However, that would be nothing but the beginning of a series of catastrophes for him. Sozomen ${ }^{79}$ provides account on how, in Hispania, Gerontius, the general and lieutenant of Constans, and one of the pillars of their regime, turned from being Constantine's right-hand man to his principal enemy. Taking advantage of the power vacuum ${ }^{80}$, he usurped the command and raised to the purple a man named Maximus. Not much is known on this character's identity; Olympiodorus ${ }^{81}$ makes him son to Gerontius himself, and Sozomen ${ }^{82}$ says he was a domesticus from

76. PLRE II, Constans 1.

77. Soz. 9. 12.

78. To be precise, he was beaten to death before the Emperor's eyes (Olym. Frag., 14)

79. Soz. 9. 13.

80. Constans would have returned to Arles again after his second promotion, during Constantine's Italian incursion; to rule their Empire from its capital.

81. Olym. Frag., 17.

82. Soz. 9. 13. 
his home; although, most likely, he was some kind of dependent, perhaps a client, like Frigeridus suggests in Gregory of Tours's quotation ${ }^{83}$. What does seem clear is that Gerontius, for some reason, preferred to use a puppet than to directly place himself in the throne, and took up residence with Maximus at Tarraco ${ }^{84}$. The reasons he had for betraying Constantine are unknown; Zosimus ${ }^{85}$ points out that it was as a result of the appointment of a new general, Justus, which may have meant a threat for his position, although Justus's appointment could have been not a cause but a consequence of Gerontius's rebellion. Clearly, he was an individual who enjoyed a great reputation among the troops; his very prestige as a warrior had been enough for Goth Sarus's withdrawal when he besieged Constantine in Valentia ( $\mathrm{vid}$. n. 23). This fame, surely, played on his favour before soldiers who were seeing how their Emperors did nothing but being frequently absent, more concerned - especially Constantine - on expanding their possesions than governing those territories already annexed. It is possible that Gerontius spread the rumour of what had been dealt with at the second embassy: that Constantine was prepared to provide Honorius with his troops to expel Alaric ${ }^{86}$, and he could have used that information to influence them against the usurper.

Reconstructing the story from then on is not easy at all, since each of the sources contribute with their own version, with cross-references, complementary and conflicting informations, quite messy and hard to interpret. Each historian, based on the few reliable data and on intuition, has opted for their preferred version, and it is what will be done here as well, but always bearing in mind that it is not possible to make categorical assertions. It is well known that in the same year 409 the mass migrations of barbarian peoples into the Peninsula took place, and that it was, to a certain extent, related with Gerontius's rebellion. Orosius ${ }^{87}$ states that it was the Honoriaci appointed as watchmen on the Pyrenees' passes by the usurpers the ones who made their way for the peoples that roamed through Gaul, who, immediately, would have started to perpetrate raids. Sozomen $^{88}$, in the same vein as the Spanish, says that these barbarian peoples entered because the Honoriaci neglected their duty, and that it

83. Greg. Tur. H.F. 2, 9. Prosper of Aquitaine (Chron., 1245) also mentions him, when he says Maximus [...] modestia humilitasque bominis [...], but he means his character more than his social background.

84. Soz. 9. 13.

85. Zos. 6. 5, 2.

86. Zos. 5. 1, 1-2.

87. Oros. 7. 40, 9.

88. Soz. 9. 12. 
took place after Constantine was deprived from his power, that is, with Gerontius already ruling the Hispanias. Zosimus, the most emphatic of them, directly points at Gerontius as the one to blame, since, according to him, the general had raised up the Barbarians that were in Gaul against Constantine III, although this account of the story omits their incursion into the Hispanias.

What all of this seems to reveal is that Gerontius, looking forward to divesting Constantine of the prefecture of the Gauls, was conscious that, on one hand, he needed to increase considerably his troops, and on the other, it was crucial to get rid of the danger that the barbarians meant when crossing the Pyrenees to Arles. That way, he killed two birds with one stone: he gained followers who could fight for his cause, and turned possible enemies into allies. It would not be very difficult to earn their support: in the end, in all the time that Constantine had been occupying the throne at Arles, aside from punctual pacts, he had not offered them any kind of foedus nor any significant alternative for their settlement. After he crossed the English Channel in 407, he had let hundreds of people roaming aimlessly over the territory he was supposed to be ruling, and, in this case, had not been better emperor than Honorius. Gerontius easily could have persuaded these people, making them see an opportunity in the alliance with him, with the promise of being allowed to settle in Hispania or of raiding at will. Furthermore, these Suebi, Vandals and Alans were at enimity with the local aristocracies ${ }^{89}$, and Gerontius would have introduced himself as a public enemy of those, after having participated in Didymus and Verinianus's overthrow. Thus, he gave order to open the frontiers, and while he increased his troops, as he needed in order to march against Constantine, the barbari were able to penetrate into the Hispanias, in an attempt to improve their situation.

During the last months of 409, news would have reached Arles, where a great alarm must have spread. Constantine hurried to send Constans, together with Decimus Rusticus ${ }^{90}$, the new praetorian prefect, to guard the towns around the area of Vienne (Isère) ${ }^{91}$, key to protect Arles, and also to recruit some barbarians ${ }^{92}$, those ones with whom they had made actual firm pacts. In addition, he sent Edobich (the general that had been appointed at the same time as Gerontius, when Sarus's attack took place)

89. SAnz SerRano 2001, 89.

90. Former magister officiorum; he also had accompanied Constans in his Spanish trip back in 408. He succeeded Apollinaris when Constans was promoted to Augustus (PRLE II, Decimius Rusticus 9).

91. Soz. 9. 13.

92. Greg. Tur. H. F. 2. 9. 
to the other riverbank of the Rhine, to recruit Alamanni and Franks for their army ${ }^{93}$. The year 410 was marked by these 'civil conflicts' between usurpers; Honorius, for his part, was not being able to take advantage of the situation on his benefit, since he continued immersed in the same troubles, considerably aggravated by the well-known sack of Rome that Alaric would carry out on summer of that same year.

Gerontius, after having put the final touches on to his plans, and leaving his puppet, Maximus, in Tarragona, advanced towards Arles ${ }^{94}$, presumably accompanied by the troops that had seconded his rebellion, and by his new barbarian recruits. The fact that he marched towards Constantine and Constans, given that he had already seized the Hispanias, and taking into account that he already had the support of the majority of the troops, leads to think that Gerontius's goal was actually to take control over the whole prefecture of the Gauls, as was mentioned, and not just the Hispanias, as generally believed: he wanted the Imperium Galliarum that Constantine had 'restored'. What is more, he must have known Constantine and Constans's plans of defending Vienne, because he did not take the road that would have taken him straight from the Pyrenees to Constantine's fortress; rather, he turned off to the north, and, taking Constans by surprise, murdered him ${ }^{95}$.

Constantine III, meanwhile, remained in Arles. Surely, the news on his son's death would not take long to reach him, but nothing is said in that regard. It only seems clear that he anxiously awaited Edobich's return with the Germanic troops that were being recruited at the other side of the Rhine. Luck was not, however, on his side: for the first time in years, political normality was returning to the court at Ravenna. Honorius, at last, realised that he would not be able to confront the troubles with the barbarians unless he got rid of the usurpers first ${ }^{96}$. He gave the deceased Stilicho a worthy successor in the western position of magister militum, and Flavius Constantius came to be the senior general.

Constantius did not waste time; he headed for Arles to end the usurpation, accompanied by the Goth $d u x$ Ulphilas $^{97}$. Gerontius, meanwhile, did the same; with Constans removed, he had cleared his way to attacking Constantine in Arles. However, when he was told about the arrival

93. Soz. 9. 13.

94. Soz. 9. 13.

95. Olyм. Frag., 17; Soz. 9. 13; Oros. 7. 42, 4.

96. Oros. 7. 42, 1.

97. After these victories, he was promoted to magister equitum per Gallias or magister equitum praesenti (PRLE II, Vlphilas). 
of Honorius's army, he fled fearful and seeked refuge back in Hispania ${ }^{98}$. While the troops leaded by Constantius had started a siege on Arles, Constantine resisted, apparently hopeful ${ }^{99}$, since there had been rumours that Edobich was not far away, and he would return accompanied by the many allies he had managed to recruit during the past few months. It seems that the news disturbed the Romans quite a lot, even making them think of withdrawing to Italy, but Constantius resolved to cross the Rhône in order to get them by surprise. He remained in a visible area, together with the infantry, and the moment Edobich arrived with his troops, ready for the battle, Ulphilas and the cavalry completed the ambush attacking from behind, and, thus, achieving the victory. Sozomen explains that Edobich was able to escape, and seeked refuge in the lands of Ecdicius, a landowner he had given service to some time ago. Ecdicius, however, handed over Edobich's head to Constantius, putting, thus, an end to Constantine III's last hope.

At the same time, in Hispania, Gerontius had been repudiated by his own troops, since they were greatly displeased by his withdrawal and flight ${ }^{100}$. They attacked his house at night and set fire to $\mathrm{it}^{101}$, and, although he could have saved himself, with the help of some servants and an Alan friend, the attacks were repeated the morning after. Feeling cornered, he beheaded his Alan friend, according to his own desire, before piercing with a sword his wife Nonnichia, who would also had implored it, probably fearful that they could end up either in the hands of their former friends or in the Roman troops's. Sozomen ${ }^{102}$ closes his dramatic ending of the story, claiming that, at the end, Gerontius stabbed the sword himself not one but three times, before sticking a dagger into his heart and, finally ending his life at the same time as a completely new and different period was starting in the political history of the Hispanias. Maximus, then, ran away to live among the barbarians ${ }^{103}$.

In the meantime, in Arles, Constantius and Ulphilas's troops had resumed laying siege to Constantine. When the usurper knew of Edobich's death, aware that he had no escape and on the verge of despair, he dropped the purple and the imperial ornaments ${ }^{104}$. Then, he seeked refuge

98. Olym. Frag., 17.

99. Soz. 9. 14.

100. Soz. 9. 13.

101. Olym. Frag., 17.

102. Soz. 9. 13.

103. Oros. 7. 42, 4.

104. Soz. 9. 15. 
and protection in the Church, receiving the sacraments ${ }^{105}$ and even being ordained as a priest. However, none of these efforts were able to stop Constantius. It was made known to the guards on the city walls that they could spare their lives if only they agreed to open the gates and hand over Constantine: no sooner said than done ${ }^{106}$. Frigeridus ${ }^{107}$ connects the haste of this attack to the possibility that there were news on the usurpation of Jovinus, so that Constantius preferred not to waste more time in Arles. After four months of besiege, the city of Arles opened its gates and Constantine III, finally, surrendered. Together with his son Julian, he was arrested and conducted to Italy ${ }^{108}$, where Honorius's men executed them nearby the river Mincio $^{109}$, before reaching Ravenna. The only part that the courtly city was to ever see of the usurper was his head, separated from his body, taken to a post for its exhibition, in Octobrer $411^{110}$.

\section{Conclusions}

It is clear that Constantine III's performance was only a small part of a trend which had started, at least, two centuries before. The situation originated from the times of Diocletian, when the prefecture system was created - and subsequently settled under Constantine I. These emperors tried to mitigate the state of continuous usurpations that had been taking place during the $3^{\text {rd }}$ century by having a praetorian prefect in charge of each prefecture, and thus, obtaining a stronger control. However, this structure, far from serving its purpose, led to the proliferation of new usurpations, this time generated within the actual prefectures, as evidenced by the previous usurpation of Magnus Maximus, one of the clearest role models followed by Constantine ${ }^{111}$.

Constantine III, then, was far from being the only usurper of his time. Neither was he the first nor the last one. However, his existence, for better or worse, somewhat shaped the transformation of the world he knew.

105. Olym. Frag., 17.

106. Soz. 9. 15.

107. Greg. Tur. H.F. 2 , 9.

108. Soz. 9. 15.

109. Prosp. Chron., 1234.

110. Cons. Const. s. a. 411

111. On usurpers and usurpations, $c f$. Flaig 1997, 15-33; Martin 1997, 47-62; Neri 1977, 71-86; OмIssi 2018. 
For that reason, it is striking how unusual it is to find authors ${ }^{112}$ that dedicate a single chapter in exclusive to analyse his figure. He is, of course, frequently mentioned, but in the way of a sidekick of History, whose importance consisted in just a punctual connection with the 'real' main characters (Honorius, Stilicho, Alaric, etc.).

Studying thoroughly this period of usurpation as a whole, with no partitions, considering it an independent entity and not just a bunch of background facts, allows to build a more precise dating of events, and to support the starting-point hypothesis: Constantine III, unlike his predecessors, was able to go a much longer way and to hold power for much more time not only because he immediately gave the troops the answer required, but mainly because he had an actual political agenda, which was resolutely developed, at least until 409 A. D.

Imitating the model inspired by the Gallic Empire, improved with certain aspects borrowed from Constantine I, he understood that the axis that Britain, Gaul and Spain made could be developed like a symbiotic entity, which would be much more effective for its defence than the independent action of each territory. The problem was that Constantine, based on a valid idea, which could have succeded once he annexed the whole Prefecture of Gaul, failed in making it flourish. After a promising beginning, he failed in the integration of the peoples roaming through the territory. He did strengthen the eastern flank, and the control over the south as well, but, undoubtedly, it was a great mistake to leave (perhaps for not having logistics and troops enough for it) all those groups unintegrated, for it would turn against him and his provinces when Gerontius betrayed him.

In a way, it can be stated that Constantine's role was necessary, taking into account how lacking political regeneration and government were the western provinces, and knowing how Honorius disregarded his duties, but in the end he fell in the same mistakes as the Emperor. The underestimation that so frequently was done of the Germanic tribes played against everyone. Not because they were the destructive threat pictured in the sources; simply, because an element of such demographic dimensions could not be ignored.

The troops prompted usurpers to the purple just because they expected a proper leadership, and Constantine exceeded all expectations in the beginning. In less than two years, he went from an anonymous solider in faraway Britain to the leader of the whole Prefecture of Gaul,

112. There are, of course, exceptions, such as StevENS 1957, 316-347or DrinKWATER 1998, 269-298. 
counting on very reduced troops and scarce resources, meaning a real threat to Honorius. To regard him as nothing more than an opportunist, whose success resided in a mere exploitation of the complicated situation lived by the West at the time, is quite simplistic. This episode actually serves as example of the transformation experienced by the political, military and social structures thoughouth the western $5^{\text {th }}$ century. However, it is also true that the deeds achieved were discredited when Constantine chose to prioritize the expansion of his power to Italy rather than strengthening what was already built.

The consequences for the Hispanias are well-known: indelible demographic changes. After Gerontius's betrayal, mass migrations of Suebi, Vandals and Alans entered the Iberian Peninsula, picturing a whole new-configured map, which Romans from then on could only attempt to pacify and settle with consecutive foedera. Despite Constantine III's project did not have a good ending for himself or his sons, he did, paradoxically, a great favour to Honorius: only when the Emperor realised of the actual threat that the usurper meant, and that with Constantine ruling he could not face the uncontrolled migratory flows, he gave Flavius Constantius the power once holded by Stilicho, and the Roman West was able to go on for some sixty-five years more.

\section{Bibliography}

Álvarez JimÉnez, David (2013): «La otra ruptura del limes en el 406: la piratería en las provincias occidentales del Imperio", in Oliveira, F. de, Brandao, J. L., Gil Mantas, V. and Sanz Serrano, R. (eds.): A queda de Roma e o alvorecer da Europa, Coimbra: Imprensa da Universidade de Coimbra, 83-101.

ARCE, Javier (1982): El último siglo de la España romana: 284-409, Madrid: Alianza Editorial.

Arce, Javier (2007): Bárbaros y romanos en Hispania. 400-500 A.D., Madrid: Marcial Pons.

Blockley, Roger C. (1981): The Fragmentary Classicising Historians of the Later Roman Empire: Eunapius, Olympiodorus, Priscus and Malchus, 2, Liverpool: Francis Cairns.

Callu, Jean-Pierre (1969): La politique monétaire des empereurs romains de 238 à 311, Paris: É. de Boccard.

Chastagnol, André: (1973): «Le repli sur Arles des services administratifs gaulois en l'an 407 de notre ère", Revue Historique, 249 (1), 23-40.

Esmonde-Cleary, Simon (1989): The Ending of Roman Britain, London: Routledge. 
Evans, Arthur J. (1887): "On a Coin of a Second Carausius, Caesar in Britain in the Fifth Century", Numismatic Chronicle, 7, 509-534.

Depeyrot, Georges (1987): Le Bas-Empire Romain. Economie et Numismatique (284-491), Paris: Errance.

DePEyrot, Georges (1996): Crisis e inflación entre la Antigüedad y la Edad Media, Barcelona: Crítica.

DrinkWATER, John F. (1998): "The Usurpers Constantine III (407-411) and Jovinus (411-413)", Britannia, 29, 269-298.

FAnNing, Steven C. (1992): "Emperors and Empires in Fifth-Century Gaul», in Drinkwater, J. F. and Elton, H. (eds.): Fifth-century Gaul: a crisis of identity?, Cambridge: Cambridge University Press, 288-297.

FERnÁNDEZ UBIÑa, José (1982): La crisis del siglo III y el final del mundo antiguo, Madrid: Akal.

Flaig, Egon (1997): "Für eine Konzeptionalisierung der Usurpation im Spätrömischen Reich», in Paschoud, F. and SzIDAT, J. (eds.): Usurpationen in der Spätantike, Stuggart: Franz Steiner Verlag, 15-33.

Frere, Sheppard (1973): Britannia. A History of Roman Britain, London: Routledge and Kegan Paul.

Heather, Peter (2006): The Fall of the Roman Empire, London: PanMacmillan.

Hejjmans, Marc (2007): "Constantina urbs. Arles Durant le IVe siècle: une autre résidence impériale?", in Demandt, A. and Engemann, J. (eds.): Konstantin Der Grosse. Geschichte, Archäologie, Rezeption, Trier: Reinisches Landesmuseum Trier, 209-220.

Kulikowski, Michael (2000): "Barbarians in Gaul, Usurpers in Britain», Britannia, 31, 325-345.

Martin, Jochen (1997): "Das Kaisertum in der Spätantike», in Paschoud, F. and SzIDAt, J. (eds.): Usurpationen in der Spätantike, Stuggart: Franz Steiner Verlag, 47-62.

Martín González, Saúl (2007): "Huérfanos del Imperio. Ejércitos privados y traidores ante el ocaso del orden romano", in Echevarría, F. and Montes, M. ${ }^{a}$ Y. (eds.): Actas del VI Encuentro de Jóvenes Investigadores, Madrid: Departamento de Historia Antigua de la Universidad Complutense, 179-190.

Martindale, John R. (1980): The Prosopography of the Later Roman Empire. Volume II: A.D. 395-527, Cambridge: Cambridge University Press $=$ PLRE II.

Matthews, John (1975): Western Aristocracies and Imperial Court. A.D. 364-425, Oxford: Clarendon.

Neri, Valerio (1997): "L'usurpatore come tiranno nel lessico político della Tarda Antichitá", in Paschoud, F. and SzIDat, J. (eds.): Usurpationen in der Spätantike, Stuggart: Franz Steiner Verlag, 71-86. 
Omissi, Adratos (2018): Emperors and Usurpers in the Later Roman Empire Civil War. Panegyric and the Construction of Legitimancy, Oxford: Oxford University Press.

Remollà, Josep A. and Pérez, Meritxell (2013): "Centcelles y el praetorium del comes Hispaniarum Asterio en Tarraco", Archivo Español de Arqueología, 86, 161-186.

SAnz Huesma, Francisco Javier (2005): «Usurpaciones en Britania (406-407): Hipótesis sobre sus causas y protagonistas», Gerión, 23 (1), 315-324.

SAnz Serrano, Rosa (1986): "Aproximación al estudio de los ejércitos privados en Hispania durante la Antigüedad Tardía», Gerión, 4, 225-264.

Sanz Serrano, Rosa (2001): "Las penetraciones bárbaras», in Bravo Castañeda, G. (ed.): La caída del Imperio romano y la génesis de Europa. Cinco nuevas visiones, Madrid: Editorial Complutense, 40-101.

Sanz Serrano, Rosa (2009): Historia de los godos. Una epopeya bistórica de Escandinavia a Toledo, Madrid: La Esfera de los Libros.

SAnz Serrano, Rosa (2016): "El nieto vestido de púrpura: Euquerio y Estilicón", in Bravo Castañeda, G. and González Salinero, R. (eds.): Crisis en Roma y soluciones desde el poder, Madrid-Salamanca: Signifer Libros, 291-309.

Stevens, Courtenay E. (1957): "Marcus, Gratian, Constantine», Athenaeum, $35,1957,316-347$. 
